\title{
"Stimulating and limiting factors for the growth of investment potential of Ukrainian insurance companies"
}

Svitlana Cherkasova iD https://orcid.org/0000-0003-1956-4992

Tetyana Kalaitan iD https://orcid.org/0000-0003-4774-4990

AUTHORS

Nadiia Rushchyshyn iD https://orcid.org/0000-0002-1198-8582

lgor Yaremko

Nataliia Yaroshevych

Svitlana Cherkasova, Tetyana Kalaitan, Nadiia Rushchyshyn, Igor Yaremko and Nataliia Yaroshevych (2020). Stimulating and limiting factors for the growth of investment potential of Ukrainian insurance companies. Investment Management and Financial Innovations, 17(1), 85-96. doi:10.21511/imfi.17(1).2020.08

ARTICLE INFO http://dx.doi.org/10.21511/imfi.17(1).2020.08

DOI Thursday, 27 February 2020

RELEASED ON Thursday, 24 October 2019

RECEIVED ON Tuesday, 21 January 2020

ACCEPTED ON (c) EY

LICENSE

This work is licensed under a Creative Commons Attribution 4.0 International License

JOURNAL "Investment Management and Financial Innovations"

ISSN PRINT 1810-4967

ISSN ONLINE $1812-9358$

PUBLISHER

LLC "Consulting Publishing Company "Business Perspectives"

FOUNDER

LLC "Consulting Publishing Company "Business Perspectives"

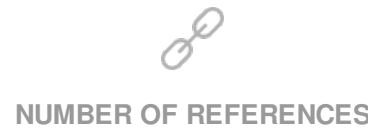

30
NUMBER OF FIGURES

2
NUMBER OF TABLES

4

(C) The author(s) 2021. This publication is an open access article. 


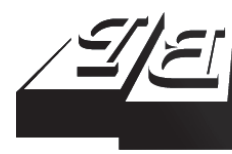

\section{BUSINESS PERSPECTIVES}

LLC "CPC "Business Perspectives" Hryhorii Skovoroda lane, 10, Sumy, 40022, Ukraine www.businessperspectives.org

Received on: $24^{\text {th }}$ of October, 2019 Accepted on: $21^{\text {st }}$ of January, 2020 Published on: $27^{\text {th }}$ of February, 2020

(C) Svitlana Cherkasova, Tetyana Kalaitan, Nadiia Rushchyshyn, Igor Yaremko, Nataliia Yaroshevych, 2020

Svitlana Cherkasova, Doctor of Economics, Professor, Department of Finance, Credit and Insurance, Lviv University of Trade and Economics, Ukraine.

Tetyana Kalaitan, PhD in Economics, Associate Professor, Department of Audit, Analysis and Taxation, Lviv University of Trade and Economics, Ukraine.

Nadiia Rushchyshyn, PhD in Economics, Associate Professor Department of Financial and Economic Security and Banking Business, Lviv University of Trade and Economics, Ukraine.

Igor Yaremko, Doctor of Economics, Professor, Department of Accounting and Analysis, Lviv Polytechnic Nationa University, Ukraine.

Nataliia Yaroshevych, $\mathrm{PhD}$ in Economics, Associate Professor Department of Finance, Lviv Polytechnic National University, Ukraine.

Svitlana Cherkasova (Ukraine), Tetyana Kalaitan (Ukraine),

Nadiia Rushchyshyn (Ukraine), Igor Yaremko (Ukraine), Nataliia Yaroshevych (Ukraine)

\title{
STIMULATING AND LIMITING
}

FACTORS FOR THE GROWTH OF INVESTMENT POTENTIAL OF UKRAINIAN INSURANCE COMPANIES

\begin{abstract}
The fact that the accumulated investment potential (IP) of insurance companies (IC) does not have a significant impact on the processes of economic growth in Ukrainian practice actualizes the task of researching the practice of investing in the activities of domestic insurers. The purpose of the study is to find out, classify and highlight the main factors that influence the formation of the Ukrainian IC' IP and give recommendations for overcoming a number of related difficulties. According to the results of investigation of the Ukrainian insurance industry development trends in 2011-2018, it was concluded that rates of their IP accumulation are insufficient. There is a decrease in the aggregate value of insurers' investment assets and a reduction in the composition of investment attractive financial instruments. Low efficiency and simplification of in vestment strategies of IC are noted. The factors that exert a stimulating and inhibitory influence on the investment processes in the Ukrainian insurance market were identified. Ways and tools were proposed to strengthen the effect of incentive factors and eliminate or minimize the effect of the considered restrictive factors that can be used in the practice of state regulation of the insurance industry of the country. Considering the examined factors should allow the state regulators making more effective decisions to improve the investment activity of insurers and enhance its importance in the development of the national economy.
\end{abstract}

\section{Keywords}

JEL Classification

\section{INTRODUCTION}

IC had the largest investment potential (IP) in the non-banking financial sector of Ukraine in the early 2000s. Thus, in 2005, the ratio of insurers' investment assets to the country's GDP was $2.8 \%$, in 2015, it went down to $1.8 \%$, and in 2018 , it reached only $1.3 \%$ (State Statistics Service of Ukraine, n.d.; National Commission for State Regulation of Financial Services Markets, n.d.). Despite the dynamic development of the insurance industry in Ukraine recently, the growth of insurance payments and the accumulation of IP of IC were slower than banks and joint investment institutions (NBU, n.d.; Ukrainian Association of Investment Business, n.d.).

Most of the limiting factors of institutional, economic, and organizational legal nature are due to the underdevelopment of the country's financial system, in particular, the lack of confidence of the population in the activities of insurance companies and the low insurance culture of society as a whole. At the same time, the development of insurance business in the country, the gradual 
increase in the volume of insurance premiums attracted, and the expansion of insurance protection types stimulate the accumulation of investment potential of domestic insurance companies.

In this context, it becomes relevant to research the existing obstacles and trends of investment development in the country's insurance sector, identify the problems that hinder the more active expansion of the IP of IC, and develop ways to overcome them.

\section{LITERATURE REVIEW}

The investment activity brings about $20-30 \%$ of their total revenue to insurers from developed countries. For Ukrainian IC, investment plays the role of ancillary (though compulsory) activity that complements insurance directly. The scale of investing in their practice depends directly on the number of premiums raised in the process of providing insurance services. Lebedynska and Remnova (2011, p. 95) highlight currency exchange rate instability, negative inflation expectations of the population, distrust in the society of financial institution activity. Wise (2018) concludes that such lack of confidence in the insurance industry potentially results in a reduction of insurance protection for business and the overall public.

Ukrainian unemployment insurance system especially obviously exposes the lack of confidence in the insurance industry. Unemployment insurance system in Ukraine is better, compared to that in the countries of Central and Eastern Europe from the viewpoint of incentives/disincentives to work but it is worse considering the income support of jobless workers and poverty prevention. It shows that less than half of the actual jobless workers in Ukraine do not have a willingness to register as unemployed. The motivation to register to base is the health care system on an insurance principle. Because under current legislation, state covers compulsory health insurance contributions for full-time students, disabled, or registered jobseekers only (Kupets, 2003). Public investments in every education level, human capital, and training infrastructure can reduce rising unemployment and social instability (Tung, 2019). Models aimed at improving the effectiveness of the investment component of insurance activity under dynamic changes are being developed by Tone, Kweh, Lu, and Ting (2019). Also, global foreign direct in- vestment has been and continues to be an important factor in the development of transition countries. By the end of 2016, the countries with the most stocks of investment in Europe were the Netherlands, the United Kingdom, Luxembourg, Germany, and France (Shuyan \& Fabuš, 2019).

The processes of increasing the investment potential of insurance companies in Ukraine are inextricably linked to solving the complexity of social problems by enhancing social stability in the society increasing the number of employed, more active development of LI systems of working citizens, the significant increase in income. Successful realization of the outlined tasks is considered as an important precondition for further growth of the investment potential of Ukrainian insurance companies.

\subsection{Classifications of factors influencing investment opportunities of IC}

In economic science, there is no single approach to the classification of factors influencing the development of the IP of insurers. Pobocha and Vorobey (2017, p. 117) distinguish:

- factors of direct impact on investment opportunities of IC: the size of formed insurance reserves and total equity;

- factors of indirect impact (economic, institutional, and legal) have predominantly institutional nature and are shaped depending on the situation in the financial market and in the country's economy as a whole.

Zalyetov (2016, p. 27) believes that the investment activity of insurers is influenced by such factors as:

- the volume, structure, capitalization and concentration of the insurance market; 
- the development of the stock market and the availability of reliable investment instruments;

- the effectiveness of state regulation of the insurance industry, etc.

Havryliak (2017) also emphasizes the presence of effective stock instruments for ensuring the successful investment activity of insurers.

\subsection{Negative institutional factors that impede investment opportunities of Ukrainian IC:}

- Imperfection of the legal regulation, lack of fluid instruments for investing, delaying the introduction of compulsory health insurance, and low level of development of life insurance in the country (Makhortov \& Ziubin, 2010, pp. 142143; Gründl, Dong, \& Gal, 2016).

- Kosova and Slobodianiuk (2016) proved that the quantitative indicators of the development of the investment component of the insurance industry of Ukraine contradict the qualitative indicators due to the inefficient structure of the formed investment portfolio. Therefore, it is necessary to implement the activities of local-global standard IC of investment performance generated by world experience.

- Insolvency of enterprises. The assessment of the solvency of the enterprises as an indicator of its financial capacity is the pillar for bankruptcy risk assessment or for valuation of the investment attractiveness of the enterprise. It is also important for the assessment of investment project beneficiaries and enterprises to privatize (Kindratska, 2019).

- Macroeconomic instability, financial crises. According to Duijm and Bisschop (2017), the pro-cyclical behavior of IC investigated in times of financial crisis has a destabilizing effect on the country's macroeconomic development. A similar conclusion was reached by Okorokova, Ulibina, Maksimenko, Rusetskiy, and Lazareva (2018) underestimating the challenges in the development of the insurance sector, both at national and regional levels, which negatively affects the processes of increasing its IP.

\section{METHODOLOGY}

Methods of economic analysis were used in order to identify the level of influence of the main development trends of the insurance industry of the country on the process of accumulation of its IP. The calculations were made based on official data of the State Statistics Service of Ukraine, the National Bank of Ukraine, and the National Commission for State Regulation of Financial Services Markets.

Investigation of the main indicators of the insurance activity development in Ukraine during 2011-2018, including the changes in the value of investment assets of insurers, the size of their financial income from investing insurance reserves, etc. were carried out based on the time series and statistical analysis, as well as calculation to determine the trends.

The assembly of IP of existing IC shapes the IP of the country's insurance sector. The most significant indicators for its assessment are:

absolute, which is determined by the value of the assets formed in the process of investing in the selected objects in accordance with Art. 31 of the Law of Ukraine "On Insurance" (Verkhovna Rada of Ukraine, 1996);

- relative, which is the ratio of the value of these assets to the country's GDP.

Based on the analysis of the mathematical dependence model of assets value of local insurers on the volume of premiums raised, the share of reinsurance and the level of insurance payments, it is proved that the volume of insurance activity and the insignificant relative indexes of reinsurance and insurance payments have a significant effect (Cherkasova \& Sorokivska, 2013, pp. 58-59).

\section{RESULTS}

\subsection{The total assets of Ukrainian IC}

At the end of 2018, the total assets of local IC amounted to UAH 63.5 billion. The total assets of IC reached UAH 40.7 billion in 2018 or $64 \%$ of assets defined by Article 31 of the Law of Ukraine "On Insurance" (Verkhovna Rada of Ukraine, 
Table 1. Annual growth rates of IC in Ukraine in 2011-2018, \%

\begin{tabular}{|c|c|c|c|c|c|c|c|c|}
\hline \multirow{2}{*}{ IP components } & \multicolumn{8}{|c|}{ Year } \\
\hline & 2011 & 2012 & 2013 & 2014 & 2015 & 2016 & 2017 & 2018 \\
\hline Total assets & 6.4 & 16.8 & 18.1 & 5.8 & -13.6 & -7.7 & 2.3 & 10.7 \\
\hline Investment assets & 3.4 & 70.5 & -22.4 & 6.9 & -10.1 & -3.7 & 2.9 & 12.7 \\
\hline Insurance premiums for risky types of insurance & -3.7 & -7.7 & 32.9 & -6.0 & 12.0 & 17.7 & 25.0 & 12.2 \\
\hline Life insurance premiums & 48.5 & 34.4 & 36.9 & -12.8 & 1.2 & 26.0 & 5.7 & 34.1 \\
\hline Technical reserves & -7.3 & 9.9 & 13.2 & -0.6 & 9.2 & 14.1 & 10.4 & 21.9 \\
\hline Mathematical reserves & 21.9 & 21.0 & 19.3 & 38.0 & 29.8 & 13.6 & 7.2 & 11.3 \\
\hline Paid authorized capital & -2.3 & 3.5 & 4.5 & -0.7 & -4.3 & -12.5 & 1.3 & -1.5 \\
\hline Financial income from asset allocation & 14.7 & 30.3 & 1.1 & 14.7 & -5.9 & 17.0 & -0.9 & 20.2 \\
\hline
\end{tabular}

1996). These types of assets are represented by investments in financial and tangible assets and claims against reinsurers. The assembly of these types of assets determines the IP of insurers and, accordingly, their real impact on the financing of economic development of the country. The main sources of establishing IP of the insurers are raised gross premiums that ensure the growth of investment assets, formed insurance reserves, paid-up share capital, funds received from asset allocation, etc. The dynamics of growth of the main components of the assembly IP of Ukrainian IC in 20112018 is shown in Table 1.

It should be noted that the largest amount of IP of the country's insurance industry was at the end of 2012, amounting to UAH 48.8 billion (National Commission for State Regulation of Financial Services Markets, n.d.). Over the next years there was a significant decrease in the value of investment assets (22.4\% in 2013) and a certain increase (12.7\%) in 2018. In 2011-2018, the total assets of Ukrainian IC increased by $40.4 \%$, while and their investment assets increased by $46.8 \%$. Higher dynamics of these processes were observed in the life insurance (LI) sector.

During the research period, the volume of premiums raised under LI contracts increased 4.3 times, while the share of this type of insurance on the market does not exceed 8\% (National Commission for State Regulation of Financial Services Markets, n.d.). The largest increase in the contributions involved in this type of insurance in this research was observed during 2011-2013 (Table 1), i.e., before the appearance of a negative trend in the social and political life of Ukraine. After the annexation of part of the country's territory and the out- break of hostilities in the east, the LI has suffered losses both in terms of premiums raised and the number of insured persons. As of the end of 2015, the total number of IC was 361: 49 "life" companies and 312 "non-life" companies (V. Kurylo, L. Kurylo, Zhovnirchyk, Kartashov, \& Sokol, 2017). It is only since 2016 when citizens started to recover their confidence towards life security as a form of their insurance protection.

Unlike Ukraine, the developed countries of the world occupy the dominant position in the insurance business by IC that sell cumulative insurance, especially LI. In the case of Ukraine, the value of total assets of life IC was 4.3 times smaller than the assets of insurers engaged in risky types of insurance in 2018. At the beginning of 2011, the difference was even higher, amounting to 8.25 times (National Commission for State Regulation of Financial Services Markets, n.d.). Predominant role in the Ukrainian market belongs to risky types of insurance, and it does not allow providing more active processes of increasing the IP of the country's insurance sector.

During the study period, the growth rate of LI reserves was much higher. Considering the longterm nature of these reserves and the use of investment income from their allocation for replenishment, this type of insurance reserves has a greater impact on increasing the IP of the country's insurance sector. Therefore, the trend towards an increase of the total amount of insurance reserves and the faster growth of the size of mathematical reserves should be considered as one that significantly influences the strengthening of the IP of local IC. Total accumulated insurance reserves by the end of 2018 amounted to UAH 27 billion, UAH 


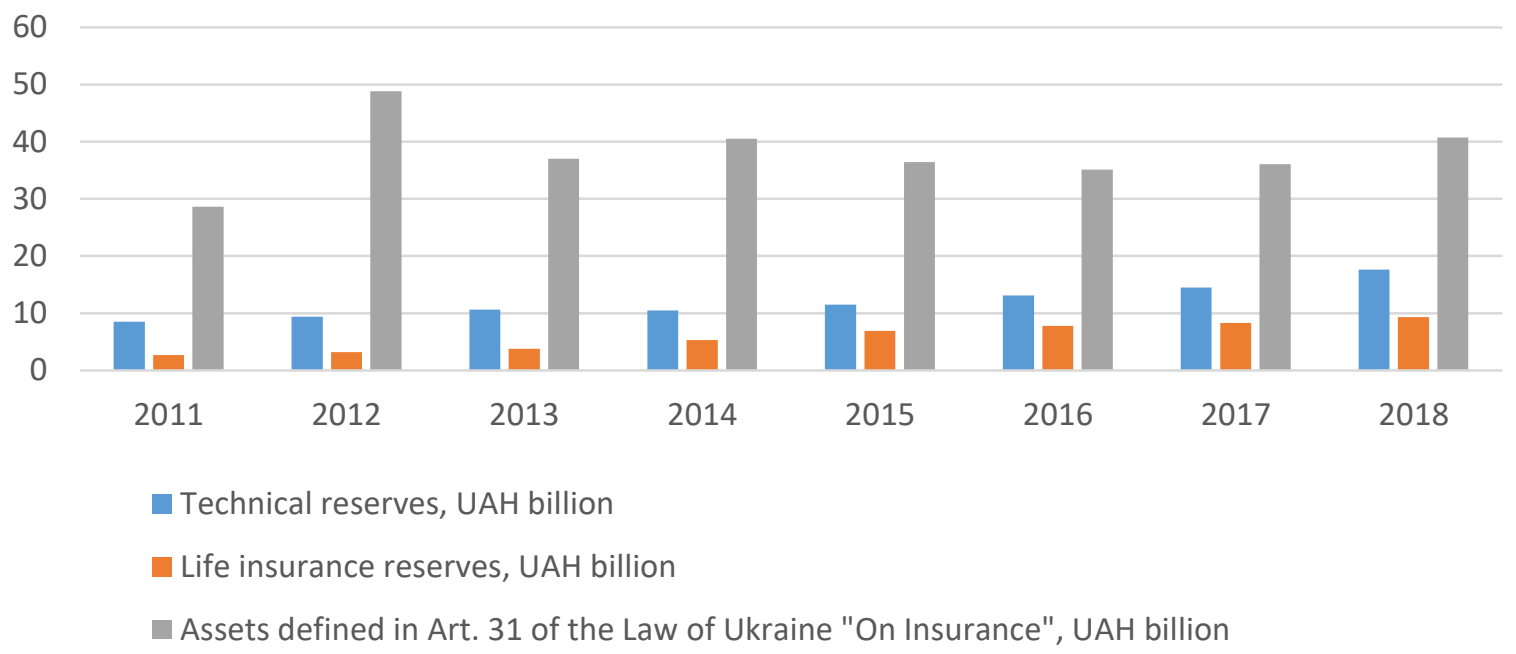

Figure 1. Amount of investment assets and insurance reserves of Ukraine in 2011-2018, UAH billion

17.7 billion, or $65.6 \%$, which accounted for technical provisions and UAH 9.3 billion, or $34.4 \%$, which accounted for mathematical reserves. Over the years of this research, the total amount of insurance reserves in the Ukrainian market increased 2.4 times, with technical reserves increasing 1.9 times and mathematical reserves 4.3 times (Figure 1).

It is proved that the gross premiums raised contain higher reserves for the growth of assets of IC than in the share of reinsurance and in the level of insurance payments, although the amount of insurance payments on the Ukrainian market in 2011-2018 increased more dynamically than the value of investment assets (110.7\% against $46.8 \%$ ) (National Commission for State Regulation of Financial Services Markets, n.d.). At the same time, the change in the share of reinsurance has a greater effect on the change in the assets value of IC than the change in the level of insurance payments. This means that the expansion of the IP of the local insurance market will be carried out only by the expansion of types of insurance, especially long-term, strengthening the degree of insurance protection in society, which will lead to an increase in the volume of such activity, and as a consequence, the investment assets of insurance organizations. An additional factor that will ensure the growth of the IP of IC, following the results of economic and mathematical modeling, may be a decrease in the volume of internal and especially external reinsurance.

The disincentive factors that limit the growth of the IP of Ukrainian IC are the "specific" structure

Table 2. Structure of total investment assets of Ukrainian IC in 2011-2018, \%

Source: Calculated by National Commission for State Regulation of Financial Services Markets (n.d.).

\begin{tabular}{|c|c|c|c|c|c|c|c|c|}
\hline \multirow{2}{*}{ Types of assets } & \multicolumn{8}{|c|}{ Year } \\
\hline & 2011 & 2012 & 2013 & 2014 & 2015 & 2016 & 2017 & 2018 \\
\hline Bank deposits & 27.3 & 17.9 & 24.5 & 22.3 & 34.6 & 32.9 & 33.9 & 34.7 \\
\hline Current accounts & 7.2 & 3.9 & 5.8 & 6.9 & 7.0 & 8.3 & 7.6 & 7.3 \\
\hline Shares & 43.7 & 61.2 & 47.0 & 44.4 & 32.7 & 22.7 & 18.4 & 12.5 \\
\hline Corporate bonds & 2.7 & 3.0 & 2.0 & 2.0 & 2.0 & 2.4 & 2.5 & 2.2 \\
\hline Government securities & 5.1 & 5.3 & 6.2 & 8.4 & 7.2 & 15.8 & 18.2 & 19.4 \\
\hline Real estate & 7.2 & 4.4 & 5.2 & 5.0 & 6.1 & 7.4 & 7.4 & 7.4 \\
\hline Rights to demand from reinsurers & 5.8 & 3.9 & 8.0 & 9.5 & 10.3 & 9.9 & 11.2 & 13.3 \\
\hline Investments in the economy of Ukraine & 0.3 & 0.1 & 0.1 & 0.2 & 0.0 & 0.1 & 0.3 & 2.8 \\
\hline Other & 0.7 & 0.3 & 1.2 & 1.3 & 0.1 & 0.5 & 0.5 & 0.4 \\
\hline Total & 100.0 & 100.0 & 100.0 & 100.0 & 100.0 & 100.0 & 100.0 & 100.0 \\
\hline
\end{tabular}


Table 3. Structure of financial income of Ukrainian IC, received from investment allocation in 2011-2018, \%

Source: Calculated by National Commission for State Regulation of Financial Services Markets (n.d.).

\begin{tabular}{|c|c|c|c|c|c|c|c|c|}
\hline \multirow{2}{*}{ Types of investments } & \multicolumn{8}{|c|}{ Year } \\
\hline & 2011 & 2012 & 2013 & 2014 & 2015 & 2016 & 2017 & 2018 \\
\hline Government and enterprise bods & 14.8 & 18.0 & 19.3 & 18.9 & 23.9 & 23.9 & 29.2 & 30.0 \\
\hline Shares & 16.9 & 14.9 & 17.0 & 20.1 & 0.4 & 0.1 & 0.1 & 0.3 \\
\hline Bank deposits & 42.4 & 48.4 & 55.4 & 48.0 & 64.4 & 68.9 & 59.4 & 59.3 \\
\hline Possession of the capital of other enterprises & 4.6 & 15.9 & 0.8 & 5.6 & 5.5 & 2.2 & 4.7 & 4.8 \\
\hline Other types & 21.3 & 2.8 & 7.5 & 7.4 & 5.8 & 4.9 & 6.6 & 5.6 \\
\hline Total & 100.0 & 100.0 & 100.0 & 100.0 & 100.0 & 100.0 & 100.0 & 100.0 \\
\hline
\end{tabular}

of assets in the investment portfolio and the low level of diversification of investments (Table 2).

The restructure of investments during 2011-2018 indicate a stable interest of insurers in allocating the investment resources in fixed deposit accounts with banking institutions, increasing the investments in government securities, such as local government bonds, as well as significant reduction in investments in equities and small amount of investment in the country's economy in the areas defined by the CMU. During the research period, there was a trend towards increasing the share of investments in the rights of claims against reinsurers, which leads to a decrease in the profitability of investment transactions. During 2011-2018, the relative indicators of investments allocated in current accounts in banks, in real estate and in corporate bonds remained almost unchanged.

The structure of the investment portfolio of IC in developed countries is totally different. Investments in securities are the major and much higher than in Ukraine. The share of claims against reinsurance organizations is missing or excessively low. Ukrainian IC have significantly increased their share of bank time deposits from $27.3 \%$ to $34.7 \%$ and to government bonds from $5.1 \%$ to $19.4 \%$ over the last eight years (Table 2). These investments are considered to be quite reliable, however, with a systemic banking crisis that is still going on in the country and a considerable amount of public internal and external debt, they pose significant threats to the financial reliability and liquidity of IC. Concentration of investments of insurers in these two directions and drawdown of investments into shares indicates a decrease in diversification of investments of investigated institutions both by types of investments and by market securities issuers. This conclusion is supported by the analysis of the financial income structure of the local IC during the research period (Table 3).

The volume of real investment by IC in priority sectors of the country's economy, defined by the government, still remains extremely low in 2019. The volume of such investments decreased from UAH 77.6 million in 2011 to UAH 34.4 million in 2018 , i.e., more than twice during the research period. Major funding is directed to the development of high-tech equipment, tourism infrastructure, housing construction, and extending loans to citizens. As practice shows, the incentives of the state for investing insurance reserves in the priority sectors of the national economy are ineffective today.

\subsection{Main stimulating factors for the growth of the IP of the IC of Ukraine}

These factors are as follows:

- The volume of premiums raised under life insurance contracts.

- The increase of mathematical and other reserves.

- Since 2015 - the technical reserves of insurers.

- The increase in premiums raised from risk insurance (only in recent years).

- The gross premiums drawn raised by concluded insurance contracts. It leads to an increase in the volume of investment transactions and insurance reserves formed. The total gross premiums received for all types of insurance amounted to UAH 49.4 billion in 2018, hav- 
ing more than doubled over the study period (National Commission for State Regulation of Financial Services Markets, n.d.).

- A stable economic and socio-political situation in the country. Because IC investment indicators increased dynamically during the periods of macroeconomic stability.

- Leading development of LI in comparison with other types of insurance protection.

- An increase in the proportion of safe and high-income investment items in insurer portfolios.

- Appearance of the first experience at the end of 2018 of transferring investment assets of two local IC to AMC management. It led to a positive growth dynamics of insurance assets value. However, this mechanism of interaction between insurers and asset management companies has not yet been properly spread in Ukraine.

- Purification of the local stock market from poor investment tools.

As a whole, the insurance industry of Ukraine has undergone a trend to decrease or slightly increase the size of paid-up share capital in recent years, which is a consequence of the elimination of insolvent IC and market consolidation. Therefore, this factor had no effect on the growth of the IP of the Ukrainian insurance sector.

\subsection{Disincentive factors and risks for the IP}

These factors are as follows:

- Diversification reduction in insurers' investment portfolios.

- Insignificant volumes of real investments of IC in priority sectors of the economy.

- The lack of a stable trend to increase the amount of financial income from investments made in 2011-2018 indicates the lack of effectiveness of investment strategies of the studied financial institutions.
- The structure of types of insurance protection, the predominant share of which belongs to the risky types of insurance. At the end of the research period, the share of raised premiums from risk insurance was $92.1 \%, 7.9 \%$ of which corresponded to LI income (National Commission for State Regulation of Financial Services Markets, n.d.). During the research period, the ratio between the gross insurance premiums for risky types of insurance and LI has not significantly increased in favor of the latter, which is characterized not only by more active but also insufficient expansion of LI in the country.

- The amount of gross premiums transferred to reinsurance, especially in the case when they are transferred to non-residents. During 2011-2018, the level of gross reinsurance premiums transferred was sufficiently high, ranging from $11.7 \%$ in 2012 to $42.2 \%$ in 2017 . In 2018 , one third of total gross premiums raised were transferred to reinsurers, $83.3 \%$ of which were received by residents and $16.7 \%$ by nonresidents. In the last-year research, total compensation by reinsurers was only $19.1 \%$. That is not more than a fifth of insurance payments (National Commission for State Regulation of Financial Services Markets, n.d.). It confirms the negative impact of reinsurance transactions on the IP of the investigated financial institutions in connection with the withdrawal funds from their business.

- Poor investment strategies. This is the result of the dynamics of financial income received by IC from the investment resource allocation in the selected assets (Table 1). A significant increase in financial income for this type of transactions occurred after their decrease in previous years. In some years, research investment transactions were unprofitable, which indicates the high risk of the selected investment strategies.

- The socio-political and economic instability in Ukraine, which led to a deterioration of favorable investment conditions by IC and created new risks in their activities. Part of the assets of insurers was lost in the occupied territories. 


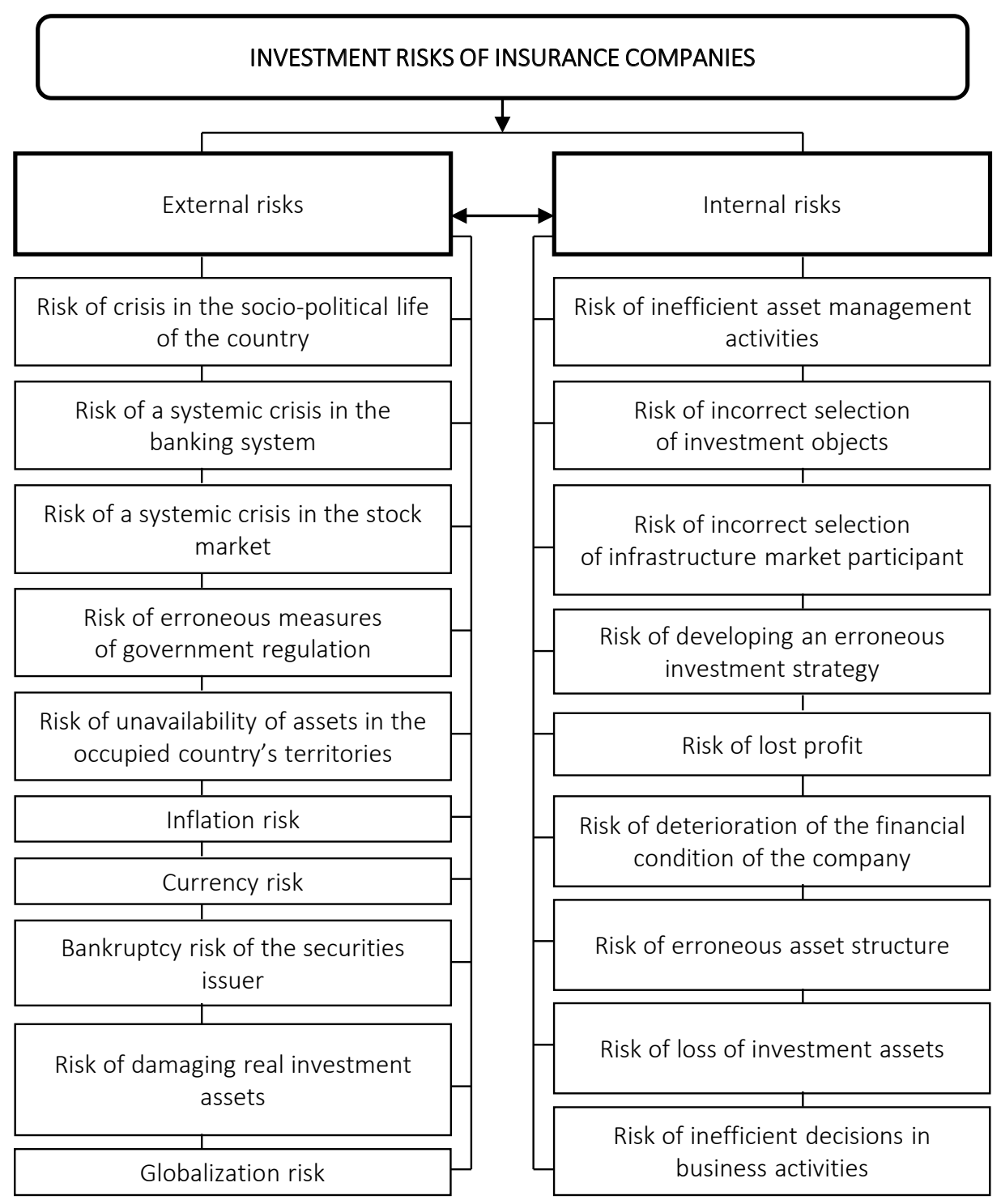

Figure 2. List of risks of IC investment activity

- The limited ability of insurers to allocate their investments in securities of foreign issuers. The maximum standards of this type of investment are determined by national legislation and apply only to high-quality securities. Foreign investment of local insurers and the fragile situation on the country's foreign exchange market discourage its growth.

- Risks of the internal environment through the complexity of the investment process and financial instruments, the involvement of a large membership of infrastructure market players, the use of unreliable information, which leads to inefficient investment decisions.
- Risks of the globalization and internationalization of the global financial space.

- Appearance of new types of risks in the investment activity of IC, including those caused by mistakes made in the state regulation of the investment activity of IC (Figure 2). Investment risks, being a separate entity for most IC, are not yet distinguished, their impact on economic performance is usually dependent on random external and internal factors. This quires the establishment of a specialized structural unit with investment risk management functions or the transfer of functions of creating and managing the formed investment portfolio to a professional market participant (AMC). 


\subsection{Comparison of stimulating and limiting factors}

Recent research makes it possible to conclude that there are both stimulating and limiting factors regarding the development of the IP of the insurance industry of the country. The grouping is shown in Table 4.

Table 4. Stimulating and limiting factors of IP development of the Ukrainian insurance sector

\begin{tabular}{|c|c|}
\hline \multicolumn{2}{|c|}{$\begin{array}{l}\text { Factors that influence the development } \\
\text { of the IP of the Ukrainian insurance sector }\end{array}$} \\
\hline Stimulating & Limiting \\
\hline $\begin{array}{l}\text { Increase in the value of } \\
\text { insurance industry assets } \\
\text { due to the development of } \\
\text { insurance activities }\end{array}$ & $\begin{array}{l}\text { Developed insurance structure, } \\
\text { the main place in which } \\
\text { belongs to risk types }\end{array}$ \\
\hline $\begin{array}{l}\text { Increase in gross and net } \\
\text { premiums raised over the last } \\
\text { five years }\end{array}$ & $\begin{array}{l}\text { Absence of a stable trend to } \\
\text { increase the amount of annual } \\
\text { financial income from insurers' } \\
\text { investments }\end{array}$ \\
\hline $\begin{array}{l}\text { Advanced development of } \mathrm{LI} \\
\text { compared to risky types of } \\
\text { insurance }\end{array}$ & $\begin{array}{l}\text { Reduction or a slight increase } \\
\text { in the amount of paid } \\
\text { authorized share capital of } \\
\text { insurers during some years }\end{array}$ \\
\hline $\begin{array}{l}\text { Increase in all types of } \\
\text { insurance reserves }\end{array}$ & $\begin{array}{l}\text { A significant amount of } \\
\text { reinsurance gross premiums } \\
\text { raised }\end{array}$ \\
\hline $\begin{array}{l}\text { Advanced growth of the size } \\
\text { of mathematical reserves } \\
\text { compared to technical } \\
\text { insurance reserves }\end{array}$ & $\begin{array}{l}\text { Loss of part of assets of IC } \\
\text { as a result of the occupation } \\
\text { of territory and hostilities in } \\
\text { eastern Ukraine }\end{array}$ \\
\hline $\begin{array}{l}\text { Increase in the number of } \\
\text { people insured under LI } \\
\text { contracts }\end{array}$ & $\begin{array}{l}\text { Advanced growth of insurance } \\
\text { payments compared to an } \\
\text { increase in investment assets }\end{array}$ \\
\hline $\begin{array}{l}\text { An increase in the amount } \\
\text { of financial income from the } \\
\text { allocation of investments in } \\
\text { government securities }\end{array}$ & $\begin{array}{l}\text { Predominance in the national } \\
\text { market in terms of the } \\
\text { composition and value of } \\
\text { assets of risk IC over life IC }\end{array}$ \\
\hline $\begin{array}{l}\text { An increase in the amount } \\
\text { of financial income from } \\
\text { the allocation of insurers' } \\
\text { investment resources on bank } \\
\text { time deposits }\end{array}$ & $\begin{array}{l}\text { Emergence of new types of } \\
\text { external and internal risks in } \\
\text { the investment activity of IC }\end{array}$ \\
\hline $\begin{array}{l}\text { Appearance of the first } \\
\text { experience of transferring } \\
\text { investment assets of insurers } \\
\text { to the professional manager } \\
\text { (AMC) }\end{array}$ & $\begin{array}{l}\text { Decrease in the level of } \\
\text { investment diversification in } \\
\text { investment strategies of IC }\end{array}$ \\
\hline $\begin{array}{l}\text { Possibility of allocating } \\
\text { investments in reliable and } \\
\text { high-income bonds of Ukraine }\end{array}$ & $\begin{array}{l}\text { Decrease in the share of } \\
\text { investments in securities in } \\
\text { the total volume of insurers' } \\
\text { investments }\end{array}$ \\
\hline $\begin{array}{l}\text { Increase in the share of safe } \\
\text { and high-income investment } \\
\text { items in insurer portfolios }\end{array}$ & $\begin{array}{l}\text { Limited opportunities for } \\
\text { local insurers to allocate } \\
\text { investments in securities of } \\
\text { foreign issuers }\end{array}$ \\
\hline $\begin{array}{l}\text { Purification of the local stock } \\
\text { market from low quality and } \\
\text { «junk» stocks }\end{array}$ & $\begin{array}{l}\text { Minor volumes of real } \\
\text { investment in priority sectors } \\
\text { of the national economy }\end{array}$ \\
\hline
\end{tabular}

\section{DISCUSSION}

Stimulating and limiting factors regarding the development of the IP of the insurance industry of Ukraine were highlighted and compared, new types of risks were discussed. All mentioned risks are subject to classical type statistics, that is, the larger the groups, the smaller the risk; a reduced risk provides an emergence of benefit to the management of the portfolio )Mualem \& Zaks, 2019). The weak part of the organizational and economic mechanism for managing the investment risks of IC in Ukraine is the lack of a specialized structural unit that is responsible for implementing the selected investment strategies. Given that the principles and foundations of investing are not the same for different financial institutions, each insurance company must develop its on investment risk management system in accordance with its needs, market conditions, and regulatory requirements. To mitigate the operating risks, such protection as a comprehensive agreement is provided by comprehensive financial institution insurance (Bankers Blanket Bond) and professional liability insurance (Financial Institution Professional Indemnity). However, these policies are not yet widespread in Ukraine and CIS countries (Shkolnyk, Bondarenko, \& Balatskyi, 2019).

Further development of investment activity in the insurance industry of Ukraine will depend on:

- the success of the implementation of other types of insurance, especially long-term ones, which will ensure an increase in the volume of raised insurance premiums and personal formed financial resources;

- introduction of additional mechanisms and instruments that will provide real protection of property rights of insurers and insured persons during the economic crisis and political instability;

- effective stimulation of insurers' investments in priority sectors of the country's economic development;

- effective means of limiting financial risks that can ensure the financial reliability of IC in the long term; 
- properly organized system of managing investment activities and investment resources; availability of effective investment objects both in the stock market and in the real sector of the national economy;

- cooperation of IC with banking institutions, non-governmental pension funds, asset management companies in order to generate joint investment strategies;

- $\quad$ state assistance to the development of investment activities of IC by expanding its capabilities and reducing restrictions.

The investment strategies of the local IC also require significant improvement. In this regard, a significant reduction in the level of the overall risk of investment activity of IC can be ensured by:

- the development and implementation of effective systems for managing the investment resources; the use of integrated CRM modeling in assessing the attractiveness of financial instruments;

- the implementation of compliance procedures;

placing the investment resources of IC in several banks, in different currencies, for different periods, dispersing them between public and private institutions and in terms of reliability (rating) of banks;

- providing investment in government bond instruments with varying maturities, as well as in the market securities of economic entities in accordance with the integral indicator of their reliability assessment;

- determining the effectiveness of the risk mitigation methods used to discard low-performing ones, and to select the most effective ones during the risk management process.

\section{CONCLUSION}

The total volume of investment assets of Ukrainian insurers for the period 2011-2018 decreased, and the share of this indicator in the country's GDP decreased. Among the new types of risks there were identified the risks of a systemic crisis in the banking system and the national stock market, as well as those caused by errors in the state regulation of insurance activities. The decrease of financial income received from the funds' allocation in financial and tangible assets had an uncertain effect on the process of increasing the investments of insurers almost every second year during the study period.

In 2019, major funding was raised by local IC from placing funds on bank time deposits and in bonds, mainly in state ones. Income from dividends on shares and possession of the capital of other enterprises is extremely low. The relative values of return on transactions with investment resource allocation in bonds were doubled during the research period, with almost $40 \%$ increase in receipts from the funds of IC on bank deposits.

These trends allow us to come up with the conclusion that investment strategies of the Ukrainian IC are being simplified in the current context since bank deposits and government bonds are dominating in the priority investment items. These processes are mostly associated with active borrowing by the government in the local market through the issuance of government bonds and the lack of effective investment tools owing to the weak development of the local stock market. Active efforts to clean up the stock market from substandard stocks by the national regulator have led to significant reduction in insurers' investments in corporate securities since 2015.

The study has shown that the incentive effect on the accumulation of investment assets of insurers has increased the volume of activity in which LI outperformed other types of insurance protection. The increase in the size of insurance reserves had a positive impact, as well as the increase in the share of safe and high-yield investment items in the portfolios of insurers. The limiting factors include: 
- an ineffective structure of types of insurance protection in the national market;

- the predominance of assets and the number of risk insurance companies over life insurers;

- a significant proportion of reinsurance premiums transferred to reinsurance;

- a loss of part of assets in the occupied territories;

- an appearance of new types of risks in the investment activity of insurance companies.

Considering the effect of the factors studied in the article will allow the state regulators to make more effective decisions to improve the investment activity of insurers and enhance its importance in the investment support of the development of the national economy.

\section{REFERENCES}

1. Azcue, P., \& Muler, N. (2009). Optimal investment strategy to minimize the ruin probability of an insurance company under borrowing constraints. Insurance: Mathematics and Economics, 44(1), 26-34. https://doi.org/10.1016/j. insmatheco.2008.09.006

2. Cherkasova, S. V., \& Sorokivska, M. V. (2013). Suchasnyi stan ta perspektyvy rozvytku investuvannia $v$ nebankivskomu finansovomu sektori: monohrafia [Current status and prospects of investment development in the non-banking financial sector: monograph]. Lviv: Rastr-7. (In Ukrainian)

3. Duijm, P., \& Bisschop, S. (2017). Short-termism of long-term investors? The investment behavior of Dutch insurance companies and pension funds. Applied Economics, 50(31), 3376-3387. https://doi.org/ 10.1080/00036846.2017.1420898

4. Düll, R., König, F., \& Ohls, J. (2017). On the exposure of insurance companies to sovereign risk - Portfolio investments and market forces. Journal of Financial Stability, 31, 93-106. https://doi. org/10.1016/j.jfs.2017.06.008

5. Gründl, H., Dong, M., \& Gal, J. (2016). The evolution of insurer portfolio investment strategies for long-term investment. OECD Journal: Financial Market Trends, 1, 1-57. Retrieved from https://www.oecd-ilibrary.org/ finance-and-investment/theevolution-of-insurer-portfolio-investment-strategies-for-long-terminvesting_fmt-2016-5jln3rh7qf46

6. Havryliak, T. S. (2015). Zarubizhnyi dosvid formuvannia finansovoho potentsialu investytsiinoi diialnosti strakhovykh kompanii [Foreign experience of formation of financial potential of insurance companies' investment activity]. Naukovyi Visnyk NLTU Ukrainy - UNFU Scientific Herald, 25(5), 251-257. (In Ukrainian). Retrieved from https://cyberleninka. $\mathrm{ru} /$ article/n/zarubizhniy-dosvidformuvannya-finansovogo-potentsialu-investitsiynoyi-diyalnostistrahovih-kompaniy

7. Huang, E. J., Lu, E. P., \& Kao, G. W. (2016). Investment Regulation, Portfolio Allocation, and Investment Yield in the U.S. and China Insurance Industry. The Chinese Economy, 49(1), 32-44. Retrieved from https://www.researchgate. net/publication/293191260_Investment_Regulation_Portfolio_Allocation_and_Investment Yield_in_the_US_and_China_Insurance_Industry

8. Kindratska, H. (2019). The assessment of solvency of Ukrainian enterprises: problematic issues of typical methodological approaches. Economic Journal of Lesia Ukrainka Eastern European National University, 3(19). https:// doi.org/10.29038/2411-40142019-03-133-143

9. Klapkiv, Yu. (2016). Spriamuvan nia instytutsionalnoho rozvytku rynku strakhuvannia zhyttia $\mathrm{v}$ Ukraini [Directing the institutional development of the life insurance market in Ukraine]. Svit Finansiv - World of Finance, 1, 206-214. (In Ukrainian). Retrieved from http://sf.tneu.edu.ua/index. php/sf/article/view/931/939

10. Kosova, T., \& Slobodianiuk, N. (2016). Securities as an investment instrument for the insur- ance companies: challenges and opportunities. Economic AnnalsXXI, 159(5-6), 85-88. Retrieved from http://soskin.info/userfiles/ file/Economic-Annals-pdf/DOI/ ea-V159-18.pdf

11. Kupets, O. (2006). Determinants of unemployment duration in Ukraine. Journal of Comparative Economics, 34(2), 228-247. Retrieved from https://www. researchgate.net/publication/222421102_Determinants_ of_Unemployment_Duration_in_ Ukraine

12. Kurylo, V., Kurylo, L., Zhovnirchyk, Ya., Kartashov, Ye., \& Sokol, S. (2017). The development of the insurance market of Ukraine amid the global trends in insurance. Investment Management and Financial Innovations, 14(1-1), 211-216. https://doi.org/10.21511/ imfi.14(1-1).2017.07

13. Lebedynska, L. D., \& Remnova, L. M. (2011). Investytsiinyi potentsial bankiv ta strakhovykh kompanii [Investment potential of banks and insurance companies]. Chernihivskyi naukovyi chasopys Chernihivskoho derzhavnoho instytutu ekonomiky i upravlinnia. Seriia 1: Ekonomika i upravlinnia - Scientific chronicle of Chernihiv State Institute of Economics and Management. Series 1: Economics and Management, 2, 91-96. (In Ukrainian). Retrieved from http://chasopis.geci.stu.cn.ua/nomer/2011/2/economics/11lldtsk. pdf

14. Lysytsia, N., Martynenko, M., Bielikova, N., Gron, O., \& Us, M. (2019). Directions of social partnership of employers and 
universities in the sphere of economic education in Ukraine. Entrepreneurship and Sustainability Issues, 7(1), 336-352. http://doi. org/10.9770/jesi.2019.7.1(25)

15. Makhortov, Yu. O., \& Ziubin, V. M. (2010). Vplyv investytsiinoho potentsialu strakhovykh kompanii na rozvytok ekonomiky [Influence of investment potential of insurance companies on economic development]. Ekonomichnyi visnyk Donbasu - Donbas Economic Herald, 2(20), 139-144. (In Ukrainian). Retrieved from http://dspace.nbuv.gov.ua/handle/123456789/23926

16. Mualem, E., \& Zaks, A. (2019). Risk premiums in life insurance. Insurance Markets and Companies, 10(1), 1-8. https://doi. org/10.21511/ins.10(1).2019.01

17. National Bank of Ukraine (NBU). (n.d.). Osnovni pokaznyky diialnosti bankiv Ukrainy [Main indicators of Ukrainian banks' activity]. (In Ukrainian). Retrieved from https://bank.gov.ua/statistic/supervision-statist/data-supervision

18. National Commission for State Regulation of Financial Services Markets. (n.d.). Pidsumky diialnosti strakhovykh kompaniy: analitychni materialy Natsionalnoi komisii, shcho zdiisniuie derzhavne rehuliuvannia u sferi rynkiv finansovykh posluh [Summary of activities of insurance companies: analytical materials of the National Commission for State Regulation of Financial Services Markets]. (In Ukrainian). Retrieved from $\mathrm{nfp}$. gov.ua/ (accessed on October 30, 2019).

19. Okorokova, O., Ulibina, L., Maksimenko, P., Rusetskiy, M., \& Lazareva, G. (2018). The Assessment of the investment potential of the Insurance Sector of the Region in the Conditions of Risk and Uncertainty. International Journal of Engineering \& Technolo$g y, 3(14), 392-397$. Retrieved from https://www.researchgate.net/ publication/327682428_The_Assessment of the Investment_Potential_of_the_Insurance_Sector_of_the_Region_in_the_Conditions_of_Risk_and_Uncertainty
20. Pobocha, K. P., \& Vorobey, H. M. (2017). Potentsial investytsiinoi diyalnosti strakhovykh kompanii na finansovomu rynku Ukrainy [Potential of insurance companies' investment activity in the Ukrainian financial market]. Naukovyi Visnyk Mizhnarodnoho humanitarnoho universytetu - International Humanitarian University Scientific Herald, 25(2), 116-119. (In Ukrainian). Retrieved from http://www. vestnik-econom.mgu.od.ua/journal/2017/25-2-2017/25.pdf

21. Shkolnyk, I., Bondarenko, E., \& Balatskyi, Ie. (2019). Financial risks of the stock market: opportunities and specifics of their insurance. Insurance Markets and Companies, 10(1), 26-35. https://doi. org/10.21511/ins.10(1).2019.03

22. Shuyan, L., \& Fabuš, M. (2019). Study on the spatial distribution of China's Outward Foreign Direct Investment in EU and its influencing factors. Entrepreneurship and Sustainability Issues, 6(3), 12801296. https://doi.org/10.9770/ jesi.2019.6.3(16)

23. Srbinoski, B. (2012). Opportunity for Life Insurance Companies on Capital Market in Macedonia. Procedia - Social and Behavioral Sciences, 44, 184-192. Retrieved from https://doi.org/10.1016/j. sbspro.2012.05.019

24. State Statistics Service of Ukraine. (n.d.). Statystychna informatsiia Derzhavnoi sluzhby statystyky Ukrainy [Statistical information of the State Statistics Service of Ukraine]. (In Ukrainian). Retrieved from http://www.ukrstat. gov.ua/ (accessed on November 17, 2019)

25. Tone, K., Kweh, Q. L., Lu, W-M., \& Ting, I. W. K. (2019). Modeling investments in the dynamic network performance of insurance companies. Omega, 88, 237-247. https://doi.org/10.1016/j.omega.2018.09.005

26. Tung, L. T. (2019). Role of Unemployment insurance in Sustainable development in Vietnam: Overview and policy implication. Entrepreneurship and Sustainability Issues, 6(3), 1139-1155. https:// doi.org/10.9770/jesi.2019.6.3(6)
27. Ukrainian Association of Investment Business. (n.d.). Analitychni ohliady industrii upravlinna aktyvamy $v$ Ukraini: analitychni materialy Ukrainskoi asotsiatsii investytsiinoho biznesu [Analytical reviews of the asset management industry in Ukraine: analytical materials of investment business]. (In Ukrainian). Retrieved from http:// www.uaib.com.ua/ (accessed on July 19, 2019).

28. Verkhovna Rada of Ukraine. (1996). Pro strakhuvannya: Zakon Ukrainy № 85/96-VR vid 7.03.1996 r. zi zminamy i dopovnenniamy [On insurance: Law of Ukraine No. 85/96-BP of March 7, 1996, as amended]. Retrieved from https://zakon. rada.gov.ua/laws/show/85/96$\% \mathrm{D} 0 \% \mathrm{~B} 2 \% \mathrm{D} 1 \% 80$ (accessed on November 11, 2019). (In Ukrainian)

29. Wise, W. (2018). Life insurance company efficiency: best method and proxies. Insurance Markets and Companies, 9(1), 6-19. https://doi.org/10.21511/ ins.09(1).2018.02

30. Zalyetov, O. (2016). Derzhavne rehulyuvannya investytsiynoyi diyalnosti strakhovykh kompaniy v Ukrayini [State regulation of investment activity of insurance companies in Ukraine]. Visnyk Kyyivskoho natsionalnoho universytetu im. T. Shevchenka. Economics, 3(180), 25-32. (In Ukrainian). Retrieved from http://bulletineconom.univ.kiev.ua/wp-content/ uploads/2016/06/180.pdf 